\title{
Status clarification and disposal of Carrière's ivy names
}

\author{
Herminio Severiano Nava, Eduardo Cires* \& José Antonio Fernández Prieto \\ Área de Botánica, Departamento de Biología de Organismos y Sistemas, Universidad de Oviedo, Catedrático Rodrigo Uría s/n., E-33071 Oviedo, Spain \\ cireseduardo@gmail.com.
}

\begin{abstract}
Nava, H.S., Cires, E. \& Fernández Prieto, J.A. 2016. Status clarification and disposal of Carrière's ivy names. Anales Jard. Bot. Madrid 73(1): e031.

Carrière in 1890 published 34 names and 33 descriptions of a collection of live ivy plants. In this article we present the analysis of his work from a nomenclatural perspective. As a result, the legitimacy and even the validity of specific and some of the infraspecific names published in the work are questioned. In addition to this, and considering the benefits on keeping the nomenclatural stability, Hedera azorica Carrière, is proposed as a nomen conservandum.
\end{abstract}

Keywords: Araliaceae, Azores Islands, Hedera azorica, nomenclature, nomina conservanda.

\section{INTRODUCTION}

E.A. Carrière effectively published —arts. 29-31 of the International Code of Nomenclature for Algae, Fungi, and Plants (McNeill \& al., 2012- 34 names (Carrière, 1890), 33 of which were accompanied by descriptions, of a collection of live ivies owned by M. Honoré Defresne, a horticulturist from Vitry (Seine), which were exhibited at the Trocadéro Gardens (Paris). Some of these names have recently been used as names of accepted species in the genus Hedera L. (Araliaceae). Such is the case of Hedera azorica Carrière, a name that many authors (McAllister \& Rutherford, 1997; López González, 2001; Schäfer, 2002, 2003; Valcárcel \& al., 2003; Green \& al., 2011; Schäfer \& al., 2011) used for the plant growing on the Atlantic islands indicated by its specific epithet, and indeed attributed the name to E.A. Carrière ("Elie Abel Carrière 1818-1896"). Nevertheless, after the analysis of the work published by E.A. Carrière, the legitimacy and even the validity of publication of Hedera azorica and others, should be questioned.

\section{DISCUSSION}

In the work of Carrière (1890), no direct or indirect reference to the works of previous authors is presented (arts. 41.3 and 44.1, McNeill \& al., 2012), so the proposed names cannot, under any circumstance, be considered as new combinations. Furthermore, the types are obviously those cultivated plants by M.H. Defresne, of which no specimen was preserved.

In such a situation, the establishment of the taxonomic status of the described taxa is a priority, as E.A. Carrière did not explicitly indicate it. The use, in some cases, of binomial nomenclature might lead one to conclude that Carrière intended to describe species. However he also specified that all described plants can be also contained within the

\section{Resumen}

Nava, H.S., Cires, E. \& Fernández Prieto, J.A. 2016. Acerca de los nombres de hiedras de Carrière. Anales Jard. Bot. Madrid 73(1): e031.

Carrière en 1890 publicó 34 nombres y 33 descripciones de una colección de plantas vivas de hiedra. En este artículo se presenta el análisis de su obra desde una perspectiva nomenclatural. Como resultado, la legitimidad e incluso la validez de algunos de los nombres específicos e infraespecíficos publicados en la obra son puestas en tela de juicio. Además, teniendo en cuenta los beneficios de mantener la estabilidad nomenclatural, Hedera azorica Carrière se propone como nomen conservandum.

Palabras clave: Araliaceae, Hedera azorica, Islas Azores, nomenclatura, nomina conservanda.

"common ivy" (Hedera helix L.), even when an exotic origin might be considered: "Nous la croyons même douteuse, car tous ces lierres nous paraissent sortir du lierre commun". Indeed, he refers to the described plants as forms or varieties, for example: "H. gracilis. - Sorte de Lierre commun..."; "H. poetica.—Forme du lierre commun... "; "H. contracta.Sorte de petit Lierre commun..."; "H. aurantiaca.-Forme à très-petites feuilles... "; "H. taurica.- Forme sylvestre du Lierre commun..."; "H. hibernica.- Cette forme..." o "Quant au nombre des variétés...".

It seems clear, therefore, that E.A. Carrière described infraspecific taxa without definite indication of rank (art. 37.3, McNeill \& al., 2012). Some additional explanations from the author might help in establishing the category of described plants: "En écrivant cette note sur les Lierres, notre intention n'est pas faire de la science, mais seulement d'appeler l'attention sur des plantes commerciales...". Therefore, in case his aim was about describing commercial plants, rather than formally publishing names with a scientific purpose, the proposed names may be considered as cultivars with binomial formulation given the informative intention of his publication (art. 28, note 4, McNeill \& al., 2012). In fact some names correspond to known cultivars at that time, for example:

Hedera combwoodiana Carrière, Rev. Hort. (Paris) 62: 162 $(1890)=H$. belix "Caenwoodiana". In this case a spelling mistake leads to an incomprehensible epithet, as seems to be dedicated to Combwood, without any further explanation, being the only case referred to a person and not to a country or specific morphology.

Hedera cordata Carrière, Rev. Hort. (Paris) 62: 164 $(1890)=$ H. belix “Cordata".

Hedera purpurea Carrière, Rev. Hort. (Paris) 62: 163 $(1890)=H$. belix "Purpurea". 
In addition, $H$. caucasica Carrière, Rev. Hort. (Paris) 62: 164 (1890), was a previously known cultivar name, evidenced by the existence of $H$. caucasica Hort. ex Lavallee, Énum. Arbres: 126 (1877), nom. nud.

These are not the only coincidences, since many of the names used by E.A. Carrière had already been used by other authors. The following ten names are illegitimate at infraspecific category, by application of Art. 53 (McNeill \& al., 2012):

Hedera arborea aurea Carrière, Rev. Hort. (Paris) 62: 164 (1890), non H. helix var. aurea Hibberd, The Ivy: 96 (1872). Hedera aurantiaca Carrière, Rev. Hort. (Paris) 62: 163 (1890), nom. illeg., non H. helix var. aurantiaca Hibberd, Fl. World Gard. Guide 7: 71 (1864).

Hedera chrysopbylla Carrière, Rev. Hort. (Paris) 62: 163 (1890), nom. illeg., non Hedera belix var. chrysopbylla Hibberd, The Ivy: 85 (1872).

Hedera conglomerata Carrière, Rev. Hort. (Paris) 62: 162 (1890), nom. illeg., non $H$. belix var. conglomerata G. Nicholson, Ill. Dict. Gard. 2: 121 (1885).

Hedera contracta Carrière, Rev. Hort. (Paris) 62: 163 (1890), nom. illeg., non $H$. belix var. contracta Hibberd, The Ivy: 70 (1872).

Hedera dentata Carrière, Rev. Hort. (Paris) 62: 162 (1890), nom. illeg., non $H$. belix var. dentata (Hibberd) G. Nicholson, Ill. Dict. Gard. 2: 121 (1885) [H. coriacea var. dentata Hibberd, The Ivy: 106 (1872)].

Hedera gracilis Carrière, Rev. Hort. (Paris) 62: 163 (1890), nom. illeg., non $H$. helix var. gracilis Hibberd, Fl. World 7: 58 (1864).

Hedera bimalaica Carrière, Rev. Hort. (Paris) 62: 164 (1890), nom. illeg., non $H$. helix var. bimalaica Hibberd, Fl. World Gard. Guide 7: 57 (1864).

Hedera submarginata Carrière, Rev. Hort. (Paris) 62: 163 (1890), non $H$. helix var. submarginata Hibberd, The Ivy: 80 (1872).

Hedera taurica (Hibberd) Carrière, Rev. Hort. (Paris) 62: 163 (1890), nom. illeg., non H. helix var. taurica Hibberd, Fl. World Gard. Guide 7: 58 (1864).

Besides, H. bibernica Carrière, Rev. Hort. (Paris). 62: 163 (1890), non H. helix var. bibernica G. Kirchn., Arbor. Muscav. 419 (1864) is a nomen nudum, and consequently those subordinated ones are neither not validly published names (art. 35.1, McNeill \& al., 2012): H. bibernica aureomarginata Carrière, Rev. Hort. (Paris) 62: 163 (1890), H. bibernica aureo-marginata Carrière, Rev. Hort. (Paris) 62: 164(1890) (two simultaneous homonyms), and H. hibernica marginata Carrière, Rev. Hort. (Paris) 62: 163 (1890). The same could be applied to $H$. rhombaea foliis variegatis Carrière, Rev. Hort. (Paris) 62: 164 (1890), as H. rhombea was not validly published in its specific category.

Moreover, Durand \& Jackson (1906) considered the two above mentioned names as species, as well as other 21 binomina, making all of them synonyms of $H$. helix. From this list two species are excluded: H. dentata Carrière, Rev. Hort. (Paris) 62: 163 (1890) and H. integrifolia Carrière Rev. Hort. (Paris) 62: 163 (1890), as they were cited as synonyms (art. 36.1c, McNeill \& al., 2012) and hence there are not validly published names.
Eight of these names are illegitimate in that category (art. 53.1, McNeill \& al., 2012):

Hedera algeriensis Carrière, Rev. Hort. (Paris) 62: 164 (1890), nom. illeg., non H. algeriensis Hibberd, Fl. World 7: 57 (1864). Hedera angularis Carrière, Rev. Hort. (Paris) 62: 163 (1890), nom. illeg., non $H$. angularis (Willd. ex Schult.) DC., Prodr. (DC.) 4: 263 (1830). Aralia angularis Willd. ex Schult., Syst. Veg. 6: 698 (1820).

Hedera arborea Carrière, Rev. Hort. (Paris) 62: 164 (1890), nom. illeg., non H. arborea (L.) Sw., Fl. Ind. Occid. 1: 818 (1797) Aralia arborea L., Syst. Nat., ed. 10: 967 (1759). Dendropanax arboreus (L.) Decne. \& Planch., Rev. Hort. 16: 107 (1854).

Hedera canariensis Carrière, Rev. Hort. (Paris) 62: 163 (1890), nom. illeg., non Willd., Mag. Neuesten Entdeck. Gesammten Naturk. Ges. Naturf. Freunde Berlin 2: 171 (1808).

Hedera chrysocarpa Carrière, Rev. Hort. (Paris) 62: 162 (1890), nom. illeg., non Walsh, Trans. Hort. Soc. London 6: 42 (1825). Hedera japonica Carrière, Rev. Hort. (Paris) 62: 162 (1890), nom. illeg., non Jungh., Tijdschr. Natuurl. Gesch. Physiol. 7: 307 (1840).

Hedera palmata Carrière, Rev. Hort. (Paris) 62: 163 (1890), nom. illeg., non (DC.) Voigt, Hort. Suburb. Calcutt. 25 (1845). Gilibertia palmata DC., Prodr. 4: 256 (1830).

Hedera poetica Carrière, Rev. Hort. (Paris) 62: 163 (1890), nom. illeg., non Salisb., Prodr. Stirp. Chap. Allerton 143 (1796).

Therefore, thirteen of the names published by E.A. Carrière could be used at specific level, and H. submarginata Carrière, Rev. Hort. (Paris) 62: 163 (1890) should be added to the twelve collected by Duran \& Jackson (1906).

The work of E.A. Carrière describing these ivies fell into oblivion, largely because most of them have always been considered, as he supposed, varieties and forms of $H$. helix. Nevertheless, in recent years his work has been claimed to name the ivy from Azores Islands, as most authors (McAllister \& Rutherford, 1997; López González, 2001; Schäfer, 2002, 2003; Valcárcel \& al., 2003; Green \& al., 2011; Schäfer \& al., 2011) consider it as a new species: $H$. azorica Carrière, Rev. Hort. (Paris) 62: 163 (1890). This plant was previously identified as H. canariensis Willd. [H. belix subsp. canariensis (Willd.) Cout.] (Palhinha, 1966; Webb, 1968; Sjögren, 1973, 1984; Franco, 1984; Hansen \& Sunding, 1993), as the typical or as a variety: H. canariensis $\beta$ azorica Gand., Bull. Soc. Bot. France 46: 254 (1899). The specific identity of this plant an its independent status are clear after considering all the molecular evidence provided by Ackerfield \& Wen (2002, 2003) and Valcárcel \& al. (2003).

\section{CONCLUSIONS}

After considering the state of the current knowledge, two possible solutions are proposed: either to declare opera opressa the work (Pre. 9, McNeill \& al., 2012) "Une importante collection de Lierres" published by E.A. Carrière in 1890, which would respect the author's opinion and would avoid the problems of both the vagueness of the category and absence of types, or to propose $H$. azorica Carrière as nomen conservandum at the specific level (art. 14.1 and 12, McNeill $\&$ al., 2012), and choose a neotype to preserve its use in the sense adopted by the botanical community as currently used. 


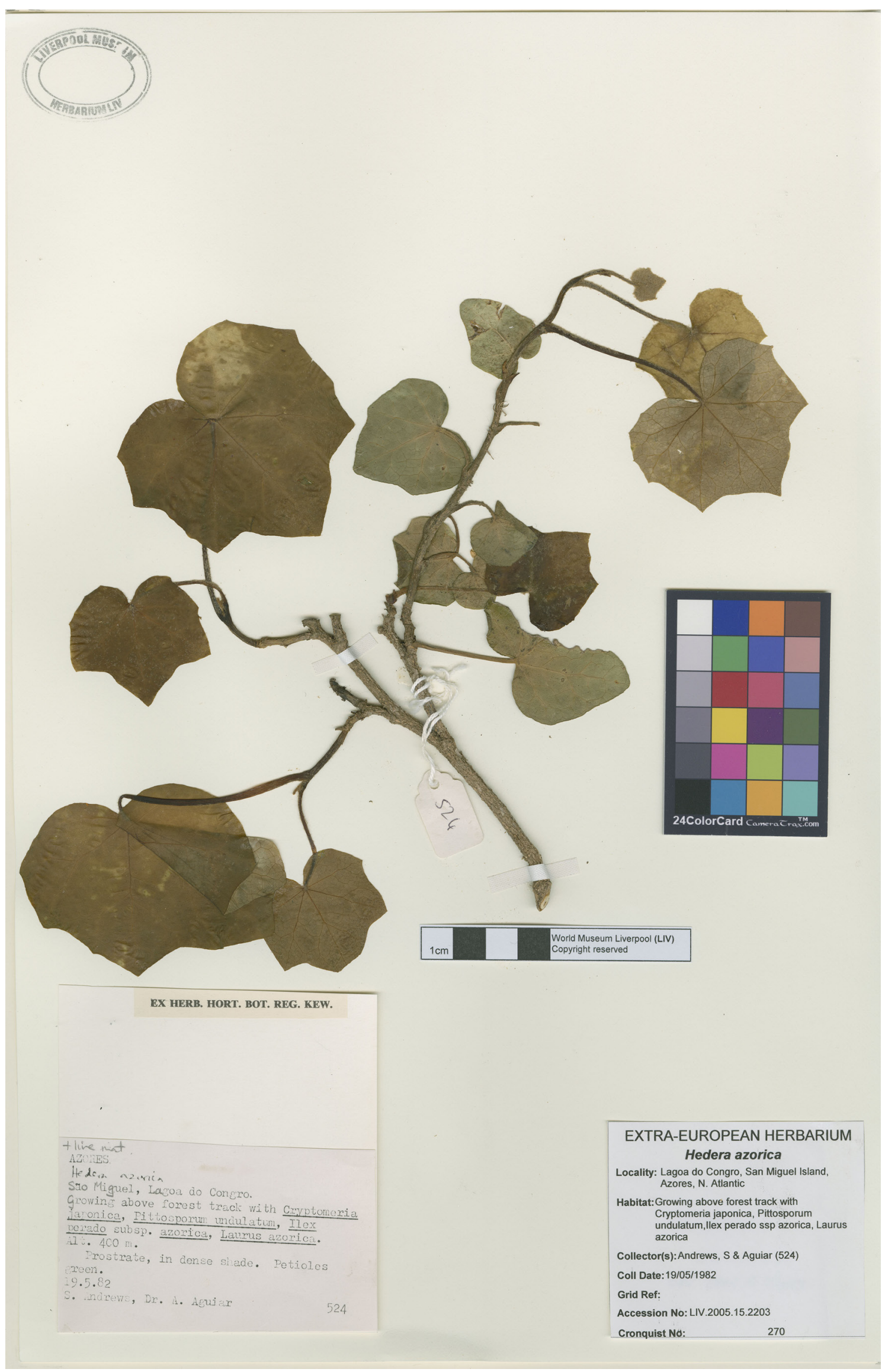

Fig. 1. Neotype of Hedera azorica Carrière (LIV; image courtesy of National Museum Liverpool). 
As in any of the cases the decision would only affect the authorship of $H$. azorica, we consider the latter nomenclatural option the less disadvantageous, and therefore, following the criteria of McNeill \& al. (2007), we will submit, to the General Committee of the International Association for Plant Taxonomy, the proposal of conservation of the name H. azorica Carrière.

In absence of any indubitable original material linked to the protologue, it seems advisable to select a neotype. A good choice for it, is a specimen, kept in the National Museum Liverpool (LIV), from San Miguel Island where many authors (e.g., Schäfer \& al., 2002, 2003; Green \& al., 2011) have confirmed the presence of $H$. azorica.

Hedera azorica Carrière, Rev. Hort. (Paris) 62: 163 (1890). TYPE: [Portugal. Azores Islands.] San Miguel Island, Lagoa do Congro, S. Andrews \& A. Aguiar \# 524, 19 May 1982 (neotype: LIV.2005.15.2203, designated here (Fig. 1).

Transcription of the neotype's labelling:

EXTRA-EUROPEAN HERBARIUM / Hedera azorica / Locality: Lagoa do Congro, San Miguel Island, Azores, N. Atlantic/ Habitat: Growing above forest track with Cryptomeria japonica, Pittosporum undulatum, Ilex perado ssp azorica, Laurus azorica / Collector(s): Andrews, S \& Aguiar (524) / Coll Date: 19/05/1982 / Grif Ref: / Accession No: LIV.2005.15.2203 / Cronquist No: 270

EX HERB. HORT. BOT. REG. KEW. / Azores / Hedera azorica / São Miguel, Lagoa do Congro. / Growing above forest track with Cryptomeria japonica, Pittosporum undulatum, Ilex perado subsp. azorica, Laurus azorica. / Alt. 400 m. / Prostrate, in dense shade. Petioles green. / 19.5.82 / S. Andrews, Dr. A. Aguiar / 524.

\section{ACKNOWLEDGEMENTS}

We are deeply grateful to Prof. John McNeill and Dr. Javier Fuertes Aguilar for their valuable corrections and suggestions, and to the anonymous reviewers for helpful comments and suggestions that greatly improved the manuscript. We also thank Wendy Atkinson (Assistant Curator of Botany at LIV) for the assistance in images collection.

\section{REFERENCES}

Ackerfield, J. \& Wen, J. 2002. A morphometric analysis of Hedera (the ivy genus, Araliaceae) and its taxonomic implications. Adansonia, sér. 3, 24(2): 197-212.

Ackerfield, J. \& Wen, J. 2003. Evolution of Hedera (the Ivy, Araliaceae): insights from chloroplast DNA data. International Journal of Plant Sciences 164(4): 593-602. http://dx.doi.org/10.1086/375423.

Carrière, E.A. 1890. Une importante collection de lierres. Revue Horticole (Paris) 62: 162-165.

Durand, T. \& Jackson, B.D. 1906. Index Kewensis, Supplementum 1: 197. Oxford University Press, Oxford.

Green, A.F., Ramsey, T.S. \& Ramsey, J. 2011. Phylogeny and biogeography of Ivies (Hedera spp., Araliaceae), a polyploid complex of woody vines. Systematic Botany 36(4): 1114-1127. http://dx.doi. org/10.1600/036364411X605100.

López González, G. 2001. Los árboles y arbustos de la Península Ibérica e Islas Baleares, vol. II. Madrid, Barcelona, México.

McAllister, H.A. \& Rutherford, A. 1997. Hedera Linnaeus. In: J. Cullen \& al. (eds.), The European Garden Flora, vol. 5(III), pp. 375-380. Cambridge University Press, Cambridge.

McNeill, J., Barrie, F.R., Buck, W.R., Demoulin, V., Greuter, D.L., Hawksworth, D.L., Herendeen, P.S., Knapp, S., Marhold, K., Prado, Prud'Homme Van Reine, W.F., Smith, G.F., Wiersema, J.H. \& Turland, N.J. (eds.). 2012. International Code of Nomenclature for algae, fungi, and plants (Melbourne Code). Regnum Vegetabile 154.

McNeill, J., A. Redhead, S. \& Wiersema, J.H. 2007. Guidelines for proposals to conserve or reject names. Taxon 56(1): 249-252.

Schäfer, H. 2002. Flora of the Azores. A field Guide. Margraf Verlag, Weikersheim.

Schäfer, H. 2003. Chorology and Diversity of the Azorean Flora. Dissertationes Botanicae 374: I-X, 1-130.

Schaefer,H., Hardy, O.J., Silva, L.F., Barraclough, T.G. \& Savolainen, V. 2011. Testing Darwin's naturalization hypothesis in the Azores. Ecology Letters 14: 389-396. http://dx.doi.org/10.1111/j.1461-0248.2011.01600.x.

Valcárcel, V., Fiz, O. \& Vargas, P. 2003. Chloroplast and nuclear evidence for multiple origins of polyploids and diploids of Hedera (Araliaceae) in the Mediterranean basin. Molecular Phylogenetics and Evolution 27: 1-20. http://dx.doi.org/10.1016/S1055-7903(02)00364-0.

Associate Editor: Inés Álvarez Received: 15-VI-2012 Accepted: 23-X-2015 